\title{
TANGGUNG JAWAB AHLI WARIS DALAM PENGEMBALIAN ASET NEGARA HASIL TINDAK PIDANA KORUPSI OLEH TERPIDANA YANG MENINGGAL DUNIA
}

\author{
Putu Aditya Witanaya Putra, Anak Agung Sagung Laksmi Dewi, Ni Made Sukaryati Karma \\ Fakultas Hukum Universitas Warmadewa, Denpasar-Bali, Indonesia
}

\begin{abstract}
Abstrak
Tindak Pidana Korupsi merupakan permasalahan yang sangat serius karena merugikan keuangan Negara. Oleh karena itu diperlukan beberapa tindakan untuk mengembalikan kerugian keuangan negara dengan cara melakukan pembayaran uang pengganti kerugian aset Negara. Penelitian ini bertujuan untuk mengetahui tanggung jawab ahli waris dalam pengembalian aset Negara dari tindak pidana korupsi yang dilakukan oleh orang tuanya yang telah meninggal dunia dan menganalisis mekanisme pembayaran uang pengganti pengembalian aset negara hasil dari tindak pidana korupsi. Penelitian ini menggunakan penelitian normative dengan pendekatan perundang-undangan. Hasil analisis menunjukan bahwa tanggung jawab ahli waris dalam pengembalian aset negara, tergantung pembuktian putusan pengadilan dan mekanisme mengenai uang pengganti dalam pengembalian aset negara sesuai dengan jumlah harta kekayaan terpidana korupsi. Kemudian, mekanisme uang pengganti pengembalian aset negara dari hasil tindak pidana korupsi dalam Undang-Undang Nomor 31 Tahun 1999 Jo Undang-Undang Nomor 20 Tahun 2001 Tentang Pemberantasan Tindak Pidana Korupsi menjelaskan terpidana korupsi wajib membayar jumlah uang pengganti sesuai hasil yang dikorupsikan oleh terpidana. Kesimpulan bahwa kerugian keuangan negara yang disebabkan oleh terpidana korupsi yang sudah meninggal dunia dilimpahkan ke ahli warisnya sesuai pembuktian dalam putusan pengadilan.
\end{abstract}

Kata Kunci: Tindak Pidana Korupsi, Tanggung Jawab, Pengembalian Uang Pengganti

\begin{abstract}
Corruption is a very serious problem because it is detrimental to State finances. Therefore, several actions are needed to recover state financial losses by paying compensation for state assets. This study aims to determine the responsibility of the heirs in returning state assets from corruption committed by their deceased parents and to analyze the payment mechanism for the return of state assets resulting from corruption. This study uses normative research with a statutory approach. The results of the analysis show that the responsibility of the heirs in returning state assets depends on the evidence of court decisions and the mechanism regarding replacement money in returning state assets in accordance with the amount of assets convicted of corruption. Then, the replacement money mechanism for returning state assets from the proceeds of corruption in Law Number 31 of 1999 in conjunction with Law Number 20 of 2001 concerning Corruption Eradication explains that corruption convicts are required to pay the amount of replacement money according to the results corrupted by the convict. The conclusion is that state financial losses caused by corruption convicts who have passed away are transferred to their heirs according to evidence in court decisions.
\end{abstract}

Keywords: Corruption, Responsibility, Refunds

\section{PENDAHULUAN}

Tindak pidana korupsi merupakan suatu tindak kejahatan luar biasa (extra ordinary crimes), karena selain merugikan keuangan negara juga merusak moralitas dan bangsa. Pengembalian kerugian keuangan negara berupa pembayaran uang pengganti tidak menghapus dipidananya terpidana tipikor (tindak pidana korupsi). Mengenai tanggung jawab pengembalian aset negara dapat diajukan gugatan perdata, dimana gugatan tersebut dibuat apabila masih belum cukupnya pembuktian atau bukti-bukti terhadap tipikor (tindak pidana korupsi) oleh terpidana. Tindak pidana korupsi merupakan kejahatan yang extra ordinary crimes, maka dari itulah dibutuhkan pula upaya-upaya yang luar biasa dalam melalukan pengembaliannya, hal itu dilakukan dengan memberlakukan undang-undang nomor 31 tahun 1999 jo undang-undang nomor 20 tahun 2001.

Untuk menangani kasus tindak pidana korupsi yang sering terjadi pada lembaga negara demi peyelenggaraan negara yang bersih dan bebas dari unsur korupsi, kolusi, dan nepotisme, maka diperlukan adanya suatu institusi kelembagaan yang mampu meyelesaikan masalah secara tidak 
memihak yang berlaku dengan objektif. Untuk memberantas tindak pidana korupsi tersebut diperlukan suatu institusi peradilan yang lengkap yang disertai dengan aturan-aturan prosedural dan juga jabatan-jabatan yang memiliki keterkaitan misalnya polisi, jaksa, lembaga permasyarakatan, advokat, dan hakim (Rasjidi \& Lili, 2001). Tindak pidana korupsi (Tipikor) merupakan suatu tindak kejahatan yang luar biasa atau extra ordinary crimes.

Pemerintah maupun aparatur penegak hukum melalui peraturan perundang-undangan sebagai instrumen hukum, telah memberikan suatu ancaman hukuman yang berat terhadap pelaku tindak pidana korupsi, sehingga dapat menimbulkan suatu efek jera terhadap pelaku maupun setiap orang yang melawan hukum yang melakukan perbuatan memperkaya diri sendiri ataupun orang lain atau suatu korporasi yang bisa merugikan keuangan negara maupun dari segi perekonomian Negara. Salah satu hal yang dapat memberikan efek jera ialah dengan cara mengharuskan si pelaku tindak pidana korupsi membayar denda dan mengharuskannya menjalani pidana kurungan penjara. Untuk memperoleh suatu hasil yang maksimal dengan adanya upaya pengembalian kerugian uang negara dalam kasus tindak pidana korupsi yang juga dapat dikenai hukuman tambahan yaitu berupa pembayaran uang pengganti sebesar yang dikorupsikan oleh si terpidana tindak pidana korupsi. Berdasarkan permasalahan yang dibahas diatas, maka penelitian baru ini bertujuan untuk mengetahui tanggung jawab ahli waris dalam pengembalian Aset Negara hasil dari Tindak Pidana Korupsi yang dilakukan oleh orang tuanya yang telah meninggal dunia dan menganalisis mekanisme pembayaran uang pengganti pengembalian Aset Negara hasil dari Tindak Pidana Korupsi.

\section{METODE PENELITIAN}

Penelitian ini menggunakan jenis penelitian hukum normatif. Penelitian hukum normatif merupakan jenis penelitian yang menilai suatu peraturan perundang-undangan dan dilakukan dengan mengadakan penelitian kepustakaan (Fajar \& dkk, 2010). Menurut (Marzuki, 2010), metode pendekatan penelitian hukum terdiri atas pendekatan perundang- undangan, pendekatan Konseptual dan pendekatan Kasus. Namun pada penelitian ini, pendekatan yang digunakan, yaitu pendekatan perundang-undangan, artinya suatu permasalahan akan dilihat dari segi aspek hukumnya dan juga dengan menelaah peraturan perundang- undangan yang kemudian dikaitkan dengan permasalahan yang dibahas, mengenai tanggung jawab ahli waris dalam pengembalian aset negara hasil dari tindak pidana korupsi yang di lakukan oleh terpidana yang meninggal dunia. Di samping itu, sumber bahan hukum yang digunakan pada penelitian ini, yaitu bahan hukum primer dan sekunder dimana menurut (Soekanto \& Mamudji, 2006) bahwa terdapat tiga sumber bahan hukum, yaitu primer, sekunder, dan tersier.

\section{HASIL DAN PEMBAHASAN}

\section{Tanggung Jawab Ahli Waris Dalam Pengembalian Aset Negara Hasil Tindak Pidana Korupsi Yang Dilakukan Oleh Orang Tuanya Yang Telah Meninggal Dunia}

Gugatan perdata terhadap ahli waris dilihat dari hal tersangkanya yang meninggal dunia pada saat dilakukannya penyidikan, sedangkan secara nyatanya telah terjadi kerugian pada keuangan negara, maka dari itu penyidik segera menyerahkan berkas-berkas perkara hasil dari penyidikan kepada jaksa pengacara negara ataupun diserahkannya juga kepada instansi yang dirugikan guna dilakukan gugatan perdata terhadap ahli warisnya. Gugatan perdata terhadap terpidana maupun dengan ahli warisnya dilakukan bilamana putusan tersebut telah berkekuatan hukum tetap (inkracht van gewijsde). Menurut Dewi, Priyanto, \& Wiryawan (2017) bahwa pertanggung jawaban perdata ahli waris pelaku tindak korupsi diatur dalam UndangUndang Nomor 20 Tahun 2001 tentang Perubahan Atas Undang-Undang Nomor 31 Tahun 1999 tentang Pemberantasan Tindak Pidana Korupsi. Ketentuan pasal 32, 33, 34 UU nomor 31 tahun 1999 jo UU nomor 20 tahun 2001 pemberantasan tindak pidana korupsi yang menegaskan bahwa, dilihat dalam hal apabila terdakwa telah meninggal dunia pada saat dilakukannya pemeriksaan pada sidang pengadilan, sedangkan telah adanya suatu kerugian pada keuangan negara, maka dari itu penuntut umum segera menyerahkan salinan berkas berita acara sidang tersebut kepada jaksa pengacara negara atau juga dapat diserahkan kepada instansi yang talah dirugikan agar dilakukannya suatu gugatan perdata kepada ahli waris dari si terpidana. Dalam hal terpidana yang meninggal dunia pada saat dilakukannya pemeriksaan pada sidang pengadilan, dan pada kenyataanya terdapat kerugian keuangan negara kepada instansi yang dirugikan untuk dilakukan gugatan perdata kepada ahli warisnya (Komisi Pemberantasn Korupsi, 2006). 
KUHperdata memberikan beberapa sikap yang dapat diambil oleh ahli waris pada saat si pewaris telah meninggal dunia, saat warisan yang ditentukan pada ahli waris maka ahli waris dapat menentukan apakah ia akan menerima ataupun menolak warisan tersebut atau ia akan menerima tetapi dengan ketentuan ia tidak akan diwajibkan membayar hutang-hutang serta kewajiban pewaris yang melebihi bagaian dalam warisan itu (Subekti, 2001). Bahwa yang dapat memiliki hak menjadi ahli waris ialah keluarga sedarah, baik itu yang sah menurut undang-undang ataupun diluar perkawinan, dan juga suami maupun istri yang hidup selama menurut peraturan-peraturan berikut ini. Bila keluarga dari suami atau istri yang hidup selama tidak ada, maka harta peninggalan akan menjadi milik negara, sedangkan yang wajib melunasi hutang-hutang dari orang yang telah meninggal, selama harga harta peninggalannya mencukupi. Dilihat pada pasal 34 UU nomor 31 tahun 1999 jo UU Nomor 20 tahun 2001 menegaskan apabila secara nyata terdapat kerugian pada keuangan negara yang diakibatkan oleh terdakwa dari Tindak Pidana Korupsi (Tipikor) sekalipun terdakwa tersebut telah meninggal dunia pada saat pemeriksaan di sidang pengadilan, maka kerugian terhadap negara dapat dikembalikan ke kas negara melalui gugatan perdata.

Dalam hal ini, negara memiliki hak/berhak untuk melakukan suatu gugatan perdata kepada ahli waris dari terdakwa terhadap benda-benda atau aset kekayaan yang diperoleh dari tindak pidana korupsi sebelum putusan pengadilan yang berkekuatan hukum tetap. Tanggung jawab hukum kepada ahli waris terpidana terhadap penjatuhan pidana mengenai uang pengganti dalam kerugian negara yakni bisa dibebankan kepada ahli waris apabila dari harta benda maupun aset kekayaan yang digunakan oleh ahli waris itu dicurigai diperoleh dari tindak pidana korupsi, maka ahli waris diharuskan mengembalikan harta benda maupun aset kekayaan yang secara berupa nyata diperoleh dari tindak pidana korupsi. Harta benda atau aset kekayaan tersebut dapat berupa tanah, rumah, deposito, tabungan maupun mobil. Apabila ahli waris terpidana tidak mampu untuk membayar uang pengganti dalam kerugian negara dari terpidana tindak pidana korupsi maka upaya pengembalian kerugian keuangan negara tidak dapat tercapai dengan baik. Bahwa tidak adanya konsekuensi hukum kepada ahli waris terpidana perkara korupsi yang tidak bisa membayar uang pengganti dalam kerugian negara terkecuali adanya suatu pembuktian atau bukti-bukti. Dimana dengan adanya buktibukti bahwa harta benda yang digunakan oleh ahli warisnya secara nyata diperoleh dari tindak pidana korupsi.

Mengenai konsekuensinya, apabila bukti-bukti tersebut tidak dapat dibuktikan sebagai perbuatan yang melawan hukum maka terdakwa harus dibebaskan dari hukuman (Raghib \& Airman, 2015). Dapat disimpulkan bahwa tidak terdapat konsekuensi hukum kepada ahli waris terpidana yang tidak bisa membayar uang pengganti dalam kerugian negara dari terpidana tindak pidana korupsi terkecuali jika terdapat suatu pembuktian dari harta kekayaan yang dicurigai diperoleh dari tindak pidana korupsi. Hal ini dikarenakan tindak pidana korupsi tersebut dilakukan oleh terpidana yang telah meninggal sehingga hakim maupun jaksa pidana tidak dapat menjatuhkan pidana terhadap ahli waris dari si terpidana tipikor. Akan tetapi, apabila terdapat harta benda atau aset kekayaan yang digunakan oleh ahli waris terpidana yang telah dicurigai berasal atau diperoleh dari suatu tindak pidana korupsi dan apabila terbukti bahwa harta kekayaan tersebut diperoleh dari tindak pidana korupsi maka jaksa pengacara negara dapat mengajukan gugatan perdata terhadap ahli waris terpidana agar harta kekayaan yang diperoleh dari tindak pidana korupsi tersebut dapat dikembalikan ke negara atau kas negara sebagai pendapatan negara. Jika aset negara tersebut terbukti dari hasil tindak pidana korupsi maka konsekuensinya setelah menerima hasil putusan dari hakim maka:

a. Terpidana haruslah membayar hasil tindak pidana korupsi (Tipikor).

b. Apabila terpidana tidak bisa mengembalikannya maka dialihkan kepada ahli waris dari terpidana.

c. Jika ahli waris dari terpidana tidak bisa membayar uang pengganti pada pengembalian hasil dari tindak pidana korupsi maka tidak ada konsekuensi hukum terhadap ahli waris dari terpidana.

\section{Mekanisme Pembayaran Uang Pengganti Pengembalian Aset Negara Hasil Tindak Pidana Korupsi}

Aset dapat diartikan sebagai setiap keuntungan yang bersifat ekonomis yang berasal dari hasil tindak pidana (Haswandi, 2017). Oleh karena itu, untuk memberantas dan mencegah Tipikor (Tindak Pidana Korupsi) mengenai pengembalian aset negara memuat ketentuan pidana yang berbeda dengan 
undang- undang yang mengatur mengenai masalah korupsi lainnya. Dalam pasal 17 jo pasal $18 \mathrm{UU}$ nomor 31 tahun 1999 jo UU nomor 21 tahun 2001 menyatakan bahwa perkara korupsi dapat dikenai dengan pidana tambahan dalam bentuk pembayaran uang pengganti. Pidana tambahan berupa uang pengganti memiliki tujuan untuk mengganti dan mengembalikan kerugian keuangan negara yang diakibatkan dari terdakwa yang melakukan perkara tipikor. Pidana tambahan berupa uang pengganti dapat memberikan rasa jera kepada terdakwa tipikor yang nantinya agar tidak mengulangi perbuatannya tersebut yang dapat merugikan keuangan negara dalam jumlah besar dan pidana tambahan uang pengganti wajib dilaksanakan oleh terdakwa perkara tipikor karena uang pengganti merupakan suatu bentuk hukuman tambahan dalam suatu perkara korupsi. Dalam peraturan perundang-undangan memberikan penekanan khusus terhadap banyaknya uang pengganti dalam perkara tipikor yakni sebanyak-banyaknya sama dengan harta benda yang didapatkan dari hasil perkara tipikor. Penjatuhan uang pengganti sebagai pidana tambahan dalam perkara tipikor diatur pada pasal 18 ayat (1) hurup b tentatang pemberantasan tipikor menjelaskan bahwa terpidana perkara tipikor diwajibkan membayar jumlah uang pengganti sebanyak yang terpidana peroleh dari tindak pidana korupsi, sedangkan pada pasal 18 ayat (2) menjelaskan apabila terpidana tidak membayar uang pengganti sesuai yang dijelaskan dalam ayat (1) hurup b dengan batas waktu selama 1 bulan sesudah memperoleh putusan pengadilan yang berkekuatan hukum tetap maka aset yang dimiliki terpidana dapat disita dan dilelang oleh jaksa demi menutupi uang pengganti tersebut. Dalam pasal 18 ayat (3) dijelaskan juga apabila terpidana tidak memiliki aset yang mampu untuk membayar uang pengganti maka dapat dipidana dengan pidana penjara yang lama waktunya tidak melebihi dari ancaman maksimum pidana pokok yang sudah ditentukan dalam putusan pengadilan sesuai dengan ketentuan yang diatur dalam UU pemberantasan tipikor.

Mengenai penuntutan pidana uang pengganti kepada terpidana perkara tipikor, jaksa berpedoman pada pasal 18 ayat (1) hurup b UU pemberantasan tipikor. Dapat dikatakan seorang hakim maupun jaksa dalam hal melakukan penuntutan maupun penjatuhan mengenai pembayaran uang pengganti kepada terpidana tipikor selalu berdasarkan dengan ketentuan yang ada dalam undang-undang mengenai pemberantasan tipikor. Dalam pasal 38 c UU pemberantasan tipikor menjelaskan apabila sesudah putusan pengadilan telah berkekuatan hukum tetap, apabila diketahui masih adanya aset kekayaan yang dimiliki oleh terpidana yang diduga diperoleh dari hasil tindak korupsi yang belum terkena perampasan untuk negara sesuai ketentuan pada pasal 38 b ayat (2) memuat penjelasan apabila terpidana tidak mampu memberi pembuktian bahwa aset kekayaan yang dimilikinya tidak didapatkan dari hasil tipikor, maka negara berhak melakukan gugatan perdata terhadap terpidana dan ahli warisnya terhadap aset kekayaan yang didapatkan sebelum putusan dari pengadilan yang berkekuatan hukum tetap.

Mengenai mekanisme pembayaran uang pengganti dalam perkara tipikor diawali dengan dibuatkannya suatu berita acara mengenai pembayaran uang pengganti berupa kwitansi tanda penerimaan/terima dari terpidana tipikor. Mengenai pembayaran uang pengganti dimana seorang jaksa sebagai eksekutor yang membuat berita acara tersebut tanpa mendaftarkan berita acara tersebut ke kejaksaan negeri. Selanjutnya terpidana menerima putusan yang sudah dijatuhi pidana, yang selanjutnya terpidana menjalankan ketentuan pidana sesuai yang dijatuhkan dalam putusan tersebut. Apabila terpidana tidak dapat melakukan pembayaran seluruh maupun setengah dari uang pengganti dalam kurun waktu selama 1 bulan setelah diperolehnya putusan yang berkekuatan hukum tetap, maka jaksa sebagai eksekutor berhak melakukan pelelangan maupun penyitaan dari aset kekayaan terpidana tipikor dengan tujuan menutupi pembayaran uang pengganti apabila terpidana tipikor tidak mampu membayarnya dan terpidana tipikor dapat dijatuhi maupun menjalani pidana tambahan berupa pidana penjara yang lama waktunya tidak melebihi dari ancaman pidana pokok yang sesuai dengan ketentuan yang diatur pada peraturan perundang-undangan mengenai pemberantasan perkara tipikor.

Adapun tata cara mengenai pengembalian aset negara berupa uang pengganti dalam perkara tipikor haruslah melalui tahapan-tahapan yang sebagaimana harus sesuai dengan ketentuan peraturan perundang-undangan yang berlaku disebutkan sebagai berikut: Tahap pertama yaitu melakukan penyidikan yang merupakan suatu tindakan untuk mencari maupun mengumpulkan bukti-bukti yang ada dan terjadi agar menemukan pelakunya, Tahap kedua adalah penuntutan yang merupakan suatu tindakan penuntut umum melimpahkan perkara pidana ke pengadilan yang berwenang agar dimaksudkannya pelimpahan penuntutan perkara tersebut ke pengadilan untuk diperiksa dan diputus, 
dan Tahap ketiga adalah eksekusi (dimana eksekusi dilakukan apabila putusan telah berkekuatan hukum tetap) (Husin \& Husin, 2016).

\section{SIMPULAN DAN SARAN \\ 1. Simpulan}

Tanggung jawab ahli waris dalam pengembalian aset negara hasil tindak pidana korupsi yang dilakukan oleh terpidana yang sudah meninggal dunia, apabila ahli waris terpidana tidak mampu untuk membayar uang pengganti dalam kerugian negara dari terpidana, maka upaya pengembalian kerugian negara tidak dapat dicapai dengan baik. Selain itu untuk memenuhi agar hal tersebut dapat berjalan baik, pihak berwenang melakukan penyitaan barang- barang yang positif diperoleh dari hasil tindak pidana korupsi dan apabila belum mencukupi, kejaksaan setempat juga akan mengadakan lelang atas hasil kekayaan tersebut agar dapat memperkecil hasil pengembalian aset negara tersebut. Mengenai adanya konsekuensi hukum pada ahli waris yang tidak mampu untuk membayar uang pengganti dalam kerugian negara dari terpidana tindak pidana korupsi, dilihat dari adanya aset kekayaan yang dilimpahkan terpidana ke ahli warisnya dengan terbukti atau tidaknya dari hasil tindak pidana korupsi.

Mekanisme pembayaran uang pengganti pengembalian aset negara hasil dari tindak pidana korupsi, dalam Undang-Undang Nomor 31 Tahun 1999 jo Undang-Undang Nomor 20 Tahun 2001, pada Pasal 18 ayat (1) hurup b menjelaskan bahwa terpidana perkara korupsi wajib membayar jumlah uang pengganti sebanyak yang terpidana nikmati dari hasil tindak pidana korupsi, pada ayat (2) dijelaskan jika terpidana tidak membayar uang pengganti paling lama satu bulan sesudah putusan pengadilan maka harta benda terpidana dapat disita dan di lelang dan pada ayat (3) ancaman mengenai tindak penjaranya tidak melebihi dari ancaman maksimum dari pidana pokoknya dan juga sesuai dengan putusan pengadilan. Adapun Mekanisme mengenai eksekusi uang pengganti yakni melalui berita acara uang pengganti kwitansi tanda terima dari terdakwa kasus tindak pidana korupsi, yang selanjutnya oleh Jaksa disetorkan ke kas Negara sebagai upaya pengembalian kerugian Negara.

\section{Saran}

Agar didalam Undang-Undang Nomor 31 Tahun 1999 jo Undang-undang Nomor 29 Tahun 2001 tentang Pemberantasan Tindak Pidana Korupsi, disarankan kepada Legislator hendaknya untuk menambahkan pasal-pasal yang secra jelas berkaitan mengenai mekanisme eksekusi uang pengganti atau tata cara pengembalian kerugian negara berupa uang pengganti ke dalam ketentuan UndangUndang Nomor 31 Tahun 1999 jo Undang-Undang Nomor 20 Tahun 2001 tentang pemberantasan Tindak Pidana Korupsi.

Agar disarankan kepada ahli waris terpidana tindak pidana korupsi untuk dapat melaksanakan tanggung jawab hukumnya yakni untuk mengembalikan harta kekayaan yang digunakan oleh ahli waris terpidana tindak pidana korupsi, dimana apabila harta kekayaan tersebut diperoleh atau berasal dari tindak pidana korupsi serta didalam hal penyelidikan terhadap harta kekayaan yang digunakan oleh ahli waris terpidana yang diperoleh dari hasil tindak pidana korupsi. Diharapkan agar lembagalembaga penegak hukum yang menangani kasus tindak pidana korupsi seperti Polisi, Jaksa, KPK serta lembaga lainnya yang berwenang dapat meningkatkan koordinasi Antara setiap lembaga-lembaga agar upaya pengembalian kerugian Negara dapat dilaksanakan dengan baik.

\section{DAFTAR PUSTAKA}

Dewi, N. M. D. J. P., Priyanto, I. M. D., \& Wiryawan, I. W. (2017). Pertanggungjawaban Perdata Ahli Waris Pelaku Tindak Pidana Korupsi dalam Mengembalikan Kerugian Negara. Kertha Semaya: Journal Ilmu Hukum, 5(1).

Fajar, M., \& Dkk. (2010). Dualisme Penelitian Hukum Normatif dan Empiris. Yogyakarta: Pustaka Belajar.

Haswandi. (2017). Pengembalian Aset Tindak Pidana Korupsi Pelaku dan Ahli Warisnya Menurut Sistem Hukum Indonesia. Jurnal Hukum Dan Peradilan, 6(1).

Husin, B. R., \& Husin, K. (2016). Sistem Peradilan Pidana Indonesia (I). Jakarta: Sinar Grafika.

Komisi Pemberantasan Korupsi, K. P. (2006). Memahami Untuk Membasmi. Jakarta: Komisi Pemberantasan Korupsi.

Marzuki, P. M. (2010). Penelitian Hukum (VI). Jakarta: Predana Media Group.

Raghib, F., \& Airman, R. (2015). Hukum Pidana. Malang: Setara Press.

Rasjidi, I. T., \& Lili, R. (2001). Dasar-dasar filsafat dan Teori Hukum. Bandung: PT. Citra Bakti. 
Soekanto, S., \& Mamudji, S. (2006). Penelitian Hukum Normatif: Suatu Tinjauan Singkat. Jakarta: PT Raja Grafindo Persada.

Subekti. (2001). Pokok-Pokok Hukum Perdata. Jakarta: Intermasa. 